UDC $330.34 ; 65.016$

DOI: https://doi.org/10.37320/2415-3583/17.8

Plyaskina Alona

Candidate of Economic Sciences,

Senior Lecturer at the Department of External Economic Activity Kherson National Technical University

ORCID: https://orcid.org/0000-0003-3680-162X

\title{
THE CONSTRUCTIVE NATURE OF THE STRUCTURAL FEATURES OF THE BUSINESS STRATEGY OF ENTERPRISE DEVELOPMENT IN THE CONTEXT OF GLOBALIZATION
}

The article presents a comprehensive methodology for the formation of a business strategy for the development of an enterprise, which makes it possible to increase its economic stability in the face of changes in the parameters of the functioning environment. It has been established that ensuring the competitiveness of an enterprise should be based on alternative options for its development, depending on the influence of external factors and the level of risk when focusing on one or another variant of the production and economic activity of the enterprise. Each enterprise is a complex system of interacting elements. Models of strategic management of the enterprise at a choice of strategy are analysed. Building principles and methods of analysis, modelling and management of economic risk is of great importance for making optimal decisions in conditions of uncertainty and conflict in solving certain economic problems, including the formation of business strategy for enterprise development.

Key words: business development strategy, criteria, factor, elements of management models, structure.

JEL classification: M21, O12

Formulation of the problem. In a market environment where there are mechanisms of competition and globalization, the stage of dynamic development plays a crucial role in ensuring the effective functioning of organizational systems. It determines the future behavior of organizational formations, qualitative changes in other stages of system development.

Analysis of recent research and publications. A significant contribution to the study and deepening of issues related to the implementation of optimal strategies for enterprise development was made by domestic and foreign scientists, namely: I. Ansoff [1], M. Baye [2], I. Blank [3], O. Gradova [4], M. Kruglov [5], O. Orlov [6], V. Tarasevich [7], J. Hyman [8] etc. However, it should be noted that the domestic economy is experiencing a shortage of important research in the field of theoretical and methodological provisions for the formation of business strategy for enterprise development, there are many controversial and unresolved issues that require further research.

Formulation of the goals of the article. Given that the business strategy of enterprise development, as a form of management, is constructive, it is its balance of the unity of the structural elements of the business development strategy that ensures the stability of the functioning of the organizational system in the external competitive environment. The constructive nature and structural feature of the business strategy of enterprise development is the purpose of this article.

Presentation of the main research material. In a business development strategy, managers use different approaches to the decision-making process - based on the desired result, the search for the strengths of their capabilities, the weakest point in the situation, the recovery of similar situations and, finally, creative thinking. Most decisions are made based on the desired result.

In order to compare alternatives and choose the best management solution, business development strategy uses criteria, the formation of which is the responsibility of senior managers. In practice, different criteria are used for decision-making in conditions of environmental risk, incomplete information and uncertainty.

Criteria are formed on the basis of a combination of relevant indicators that characterize the results of actions economic, social. The smaller these indicators, the easier it is to form criteria. Therefore, when solving problems, it is desirable to reduce several criteria to one integrated.

Variants of the developed solutions are evaluated according to the expected economic results, significance for the economy, efficiency, level of risk from the external environment when the results cannot be determined exactly, reliability of individual options. When solving a complex problem in decision-making, each manager chooses a specific strategy depending on the nature of the decision, the conditions under which it is made, for example, business development strategy. Business development strategy as a general concept of the enterprise is an action that includes the allocation of resources to achieve the ultimate goals, the choice of key objectives.

Most management tasks in enterprises are solved on the basis of empirical knowledge, which reflects the reality of its external relations. Therefore, making effective decisions often turns into creative thinking, individual abilities of the leader, his or her general outlook and experience.

The most important prerequisite for the effectiveness of the structure of the business strategy of enterprise development is the development of sound principles and their implementation and growth in practice. The main principles of the structure of business development strategy include the following principles:

1. The principle of completeness. Internal and external factors influencing the strategy are taken into account.

2. The principle of validity. Focus of the strategy on socio-economic tasks and market needs.

3. The principle of reality. The strategy is based on the use of progressive methods of their development.

4. The principle of integration. The need for a close relationship between the various factors influencing the strategy. 
5. The principle of flexibility. The strategy is forced to adjust to the constant active changes in the environment and the need for timely adaptation to them.

6 . The principle of economy. Costs must be rationally correlated with the results obtained.

When forming a business development strategy, it is better to take into account objective limitations, namely:

1. The level of available financial resources. If its own funds are not enough, the company takes unjustified risks by borrowing money at high interest rates.

2. The level of risk taken. Trying to reduce risk to a minimum reduces the range of choice of strategies.

3. Potential skills and capabilities of the enterprise. Quite often the chosen strategy requires more skills and capabilities than the company has.

4. Relationships within the working relations of the enterprise. For example, often suppliers cannot provide acceptable conditions and opportunities to work in such a way as to successfully implement the chosen strategy.

5. Opposition of competitors. Often sound strategies cannot be used due to the action of competitive forces.

Each factor of the external environment affects the ability of the enterprise to obtain competitive advantages. Behavioural research by scientists Beltiukov E.A. and Nekrasova L.A. allowed to establish the relationship between environmental factors and business development strategies.

In the business strategy of enterprise development it is necessary to take into account the basic elements of management models, the main of which are the decision-making situation, time for decision-making, resources needed to implement management, factor management system, alternatives in improving management, a system of criteria for evaluation in improving management.

In order to reduce the risk of them minimizing losses as a result of the functioning of enterprises in market conditions, caused by both the uncertainty of future working conditions and possible erroneous decisions, it is advisable to choose a rational option (strategy) for the development of an enterprise using probabilistic and statistical criteria. The use of probabilistic and statistical criteria allows the company to avoid possible losses and determine the best development strategies.

It is advisable to make a decision on the choice of a rational version of the business strategy for the development of an enterprise using the Wald criterion, the Savage criterion, the Routh-Hurwitz criterion and the Laplace criterion [9, p. 244].

Due to the weak formalization of the processes taking place in the globalization environment in which enterprises operate, in addition to quantitative criteria for evaluating solutions, qualitative criteria are of great importance. Qualitative criteria can be expressed through conditional evaluations.
When evaluating effective solutions, you can use the methods of margin analysis, when comparing additional revenues from additional costs. For example, if the goal is to achieve maximum profit, it can be achieved when the additional profits and additional costs are equal. In addition to marginal analysis, you can use the analysis of the degree of risk, "goal tree", the theory of benefits.

Expert evaluation methods, as well as technical, economic, social and combined experiments, are widely used to compare solutions.

Quantitative comparison of different indicators is possible when a group of experts is involved to evaluate decisions. The objective need to involve them in the development of management decisions is due to the fact that in most situations, managers do not have enough information. This information is retrospective, which makes it difficult to take into account many factors when developing solutions.

The effectiveness and quality of management decisions usually can be assessed by the following indicators:

1. Economic efficiency of decisions - the ratio of the effectiveness of the implementation of decisions to the cost of achieving goals.

2. Coefficient of cost-effectiveness of solutions - the ratio of regulatory costs for the implementation of decisions to the actual production costs.

3. Coefficient of timeliness of decision development the ratio of the regulatory period of decision preparation to the actual duration of decision development

4. Coefficient of quality - the ratio of prepared in a timely manner and approved draft decisions to the total number of decisions prepared during the reporting period.

Management decisions in the business strategy of enterprise development involve the use of various methods and techniques that ensure the correct choice and effectiveness of appropriate management decisions. There are certain ideas that form the models that guide the decision-making. Example:

1. Rational-deductive model, which assumes that the leader will have the ability to predict the consequences of decision-making.

2. Discrete-incremental model, which provides a full delineation and understanding of the problem, as well as the collection of relevant information for the development of various options and their rational assessment before choosing the most successful programme of action.

3. Reductionism, which is based on the belief that the problem can be reduced to its smallest component; it is possible to find logic in its entirety.

4. Universal prediction, convinced that everything can be predicted, making it responsible for the choice of solutions by computers.

Table 1 - Interrelation of environmental factors and business development strategy

\begin{tabular}{|l|c|c|c|c|}
\hline \multirow{2}{*}{\multicolumn{1}{c|}{ Environmental factors }} & \multicolumn{4}{c|}{ Business development strategies } \\
\cline { 2 - 5 } & $\begin{array}{c}\text { Cost } \\
\text { reduction }\end{array}$ & $\begin{array}{c}\text { Product } \\
\text { differentiation }\end{array}$ & $\begin{array}{c}\text { Market } \\
\text { segmentation }\end{array}$ & $\begin{array}{c}\text { Implementation } \\
\text { Responding to } \\
\text { market needs }\end{array}$ \\
\hline Influence of buyers & + & + & + & + \\
\hline Influence of suppliers & + & + & & + \\
\hline Influence of competition within the industry & + & & + & + \\
\hline Influence of market parameters & + & + & + & + \\
\hline Influence of socio-economic trends & & + & + \\
\hline
\end{tabular}

Source: [9, p. 200] 
Thus, these models reflect the development of the application of various methods in the management process, namely in making effective management decisions.

Depending on the specific conditions, direct, accurate and combined calculations are used to evaluate the solutions. Accurate mathematical calculations are used when there is a sufficient regulatory framework and known quantitative relationships between the various factors of the control object.

Conclusions. There is a close connection between the past, present and future state of efficiency of the enterprise - a state that characterizes the level of the final result and the development opportunities created over a period of time. Carefully analysing the external environment, the peculiarities of the enterprise, its strengths and weaknesses, you can form a business strategy for enterprise development, which will become a paradigm for the management of the entire enterprise. Successful development of a business development strategy is the key to success for an independent enterprise, a form of resolving conflict situations between interest groups both inside and outside the business, a way to innovate.

\section{References:}

1. Ansoff I. (1989) Strategicheskoe upravlenie [Strategic Management]. Moscow: Economy. (in Russian)

2. Baye M.R. (1999) Upravlencheskaya ekonomika i strategiya biznesa [Management economics and business strategy]. Moscow: UNITI-DANA. (in Russian)

3. Blank I.A. (1998) Upravlenie pribyl'yu [Profit management]. Kyiv: «Nika-Zentr». (in Russian)

4. Gradova A.P. (ed.) (1999) Ekonomicheskaya strategiya firmy [Economic strategy of the firm]. Saint Petersburg: Piter. (in Russian)

5. Kruglov M.I. (1998) Strategicheskoe upravlenie kompaniey [Strategic management of the company]. Moscow: Russian Business Literature. (in Russian)

6. Orlov O.O. (2002) Planuvannja dijaljnosti promyslovogho pidpryjemstva [Industrial enterprise activity planning]. Kyiv: Skarby. (in Ukrainian)

7. Tarasevich V.M. (2001) Cenovaja polytyka predpryjatyja [Price policy of the enterprise]. Saint Petersburg: Piter. (in Russian)

8. Hyman D.N. (1992) Sovremennaya mikroekonomika: analiz i primenenie [Modern microeconomics: analysis and application]. Finance and Statistics, vol. 2.

9. Beltiukov E.A., Nekrasova L.A. (2002) Vybor strategi razvitiya predpriyatiya [Choosing an enterprise development strategy]. Odesa: ONPU. (in Russian)

\section{Список використаних джерел:}

1. Ансофф И. Стратегическое управление / Под ред. Л.И. Евенко. Пер. с англ. Москва : Экономика, 1989. 519 с.

2. Байе М.Р. Управленческая экономика и стратегия бизнеса / Пер. с англ. Москва : ЮНИТИ-ДАНА, 1999. 743 с.

3. Бланк И.А. Управление прибылью. Київ : «Ника-Центр», 1998. 544 с.

4. Экономическая стратегия фирмы : учебное пособие / Под ред. А.П. Градова. СПб. : Питер, 1999. 589 с.

5. Круглов М.И. Стратегическое управление компанией : учебник для ВУЗов. Москва : Русская Деловая Литература, 1998. 768 с. 6. Орлов О.О. Планування діяльності промислового підприємства : підручник. Київ : Скарби, 2002. 336 с.

7. Тарасевич В.М. Ценовая политика предприятия. СПб. : Питер, 2001. 272 с.

8. Хайман Д.Н. Современная микроэкономика: анализ и применение. В 2-х томах / Пер. с англ. : Финансы и статистика, 1992.768 с.

9. Бельтюков Е., Некрасов Л. Выбор стратеги развития предприятия : учебное пособие. Одесса : ОНПУ, 2002. 280 с.

Пляскіна А.I.

Херсонський національний технічний університет

\section{КОНСТРУКТИВНИЙ ХАРАКТЕР СТРУКТУРНОЇ ОСОБЛИВОСТІ ДІЛОВОЇ СТРАТЕГІЇ РОЗВИТКУ ПІДПРИЕМСТВА В УМОВАХ ГЛОБАЛІЗАЦІї}

В статті доведено, що, оскільки економічні умови є динамічними та невизначеними, то одним із головних заходів, який може покращити стан сучасного підприємства на ринку, є стратегія розвитку, а саме ділова. Досліджено та систематизовано підходи щьодо структури та формування ділової стратегї̈ розвитку підприємства у відповідності до його иілей та можливостей. В статті розкрито основні рекомендачії щодо формування ділової стратегії розвитку підприємства з урахування впливу зовнішніх та внутрішніх факторів. Обгрунтовано головні иілі, які необхідно вирішувати в процесі формування стратегії розвитку підприємства, враховуючи ї об єктивні обмеження. Ділова стратегія розвитку підприємства розглядається як стратегія, яка грунтується на швидкості дій підприємства на зміну тендениіям зовнішніх проиесів суспільства, їх гнучкості; постійному пошуку $i$ запровадженню нововведень у діяльність підприємства. Доведено, щзо підприємства безпосередньо взаємодіють із зовнішнім середовищем, враховуючи тендениії розвитку глобалізаційних проиесів. Розглянуто розвиток підприємства з боку його кількісних та якісних критерїв оцінки варіантів рішень. Автор статті розглядає розвиток підприємства через його стратегічні напрями з урахуванням впливу зовнішнього середовища на підприємства. Для иьвого було уточнено характер структурної особливості ділової стратегї розвитку підприємства. В подальшому така стратегія повинна базуватися на інтенсивному розвитку підприємства. Доведено, щзо найважливішою передумовою ефективності структури ділової стратегії розвитку підприємства є розробка обтрунтованих приниипів та їх впровадження і виростання у практичні діяльності. Результати проведеного дослідження можуть бути використані керівниками підприємств для вибору обтрунтованої стратегї̈ розвитку та посилення конкурентних позицій підприємств на ринку. Результати, отримані в проиесі дослідження, можуть стати базисом для проведення перспективних наукових досліджень щодо обтрунтування $і$ формалізаціі науково-методичних підходів до формування механізму розробки стратегї розвитку підприємств.

Ключові слова: ділова стратегія розвитку, критерії, фактор, елементи моделей управління, структура. 